\title{
Effect of Boiled Water Parasite Kapok (Dendrophthoe pentandra) Leaves on Total Cholesterol Levels and Histopathology of Hepar of Hypercholesterolemic Mice
}

A. Mu'nisa ${ }^{1, a}$, Yusminah Hala ${ }^{1, b}$, A. Mushawwir Taiyeb ${ }^{1, c}$, Dwi Kesuma Sari2,

\author{
${ }^{1}$ Departemen of Biology, Universitas Negeri Makassar, JI. Daeng Tata Kampus Parangtambung \\ UNM, Makassar, 90224, Indonesia
}
${ }^{2}$ Faculty of Veterinary Medicine, Hasanuddin University, Jl. Perintis Kemerdekaan Kampus Tamalanrea, Makassar, 90245, Indonesia
aandi.munisa@unm.ac.id, byushala12@gmail.com, mtaiyeb333@gmail.com, ddwiks73@gmail.com

\begin{abstract}
Keywords: Dendrophthoe pentandra leaves, hypercholesterolemia, histopathology of hepar, total cholesterol
\end{abstract}

\begin{abstract}
This study aims to determine effect of boiled water parasite kapok (Dendrophthoe pentandra) leaves on the total cholesterol level and histopathology of hepar of hypercholesterolemic mice (mus musculus). This study used 20 ICR male mice divided into 4 treatment groups namely normal mice group, hypercholesterolemic mice group, mice group with boiled water kapok parasite at a dose of $400 \mathrm{mg} / \mathrm{kg} \mathrm{BW}$, and $800 \mathrm{mg} / \mathrm{kg} \mathrm{BW}$, respectivelly. The animal group was given boiled water kapok parasite after standard feeding and cholesterol feed for 2 weeks. The parameters observed in this study were total cholesterol levels, the amount of fat granules in the liver tissue of mice which were observed in the form of liver-preserved preparations made by paraffin method. The results showed that the administration of parasitic kapok (Dendrophthoe pentandra) at a dose of $400 \mathrm{mg} / \mathrm{kg}$ BW and $800 \mathrm{mg} / \mathrm{kg} \mathrm{BW}$ had an effect on decreasing the total cholesterol level of mice and the histopathology of hepar of showed improvement after the therapy.
\end{abstract}

\section{Introduction}

Hypercholesterolemia is also a risk factor for stroke and for peripheral arterial disease (PAD). Hypercholesterolemia is defined as plasma cholesterol levels that exceed the normal threshold and pose a strong risk factor for cardiovascular disease also some factors that are out of control that can increase the risk of hypercholesterolemia. This factor includes age, sex, and heredity. But, there are several risk factors that can be changed. For example, an unhealthy diet, being overweight, and lack of exercise. Adult total cholesterol levels are expressed high when it reaches a value of $240 \mathrm{mg} / \mathrm{dl} \mathrm{or}$ more. While in children and adolescents, the total cholesterol value that reaches a value of $200 \mathrm{mg} / \mathrm{dl}$ or more has been declared high ${ }^{(1)}$.

Dendrophthoe pentandra (L.) Miq. is one of the Indonesian mistletoes species which belong to the family of Loranthaceae. This species in commonly found grew on many different species of host plant $^{(2,3)}$.

The parasite contains quercetin, saponin and tannin flavonoids which are believed to reduce total cholesterol and LDL levels in the blood through increased excretion of bile acids and are believed to have antioxidant effects to prevent LDL oxidation and inflammatory reactions so as to prevent aortic wall changes. Flavonoids in the form of quercetin as antioxidants and anti-inflammatory can be used as hypercholesterolemic therapy ${ }^{(4,5)}$. Besides that, D. pentandra extract has also been proven as a potential source of natural antioxidant and antidiabetic compounds ${ }^{(6)}$.

This study aimed to determine the effect of boiled water parasite kapok (Dendrophthoe pentandra) leaves on the total cholesterol level and histopathology of hepar of hypercholesterolemic mice (mus musculus). 


\section{Experimental}

\section{Instruments and Materials}

The instruments used in this study were a set of tools cups, spatula, auto-pipette, stirrer, vortex, oven, water bath, centrifuge, digital scales, UV-Vis spectrophotometer, rotary evaporator, light microscope, rats scales, rats cages, syringes, Easy Touch GCU, $-20^{\circ} \mathrm{C}$ freezer, $4^{\circ} \mathrm{C}$ refrigerator.

Materials used are dried powder of parasite kapok (Dendrophthoe pentandra) leaves, cholic acid, lard, eggs quail, rat's standard feed, distilled water, HCL, Ethanol, Physiological NaCl 0.9\%, PBSazide, Paraformaldehyde(PFA), Alcohol 70\%, 80\%, 90\% and 95\%.

Experimental animals were used male mice (Mus musculus) ICR (Imprinting Control Region) strain with 18-30 g of body weight which obtained from Animal Model Hasanuddin University. All conditions of experiment and handling of the animals were conducted following the protocols approved by Health Ethics Committee of the Faculty of Medicine of Hasanuddin University. The mice were divided into four groups: control group (A), hypercholesterolemic group (B), and (C), (D) were hypercholesterolemic group with boiled water parasite kapok leaves dose of $400 \mathrm{mg} / \mathrm{kgBW}$, $800 \mathrm{mg} / \mathrm{kgBW}$, respectively.

\section{Induction of Hypercholesterolemia}

Rats in group B, C, and D were treated with hypercholesterolemic diet by force feeding. Hypercholesterolemic diet for each rat was prepare from $10 \%$ lard $(2 \mathrm{~g}), 0.02 \mathrm{~g}$ of cholic acid and $1 \mathrm{~g}$ of cooked egg yolk, then mixed with destilated water to $1 \mathrm{~mL}$.

\section{Preparation of boiled water of Parasite Kapok Leaves (Dendrophthoe pentandra)}

The parasite kapok leaves are dried at room temperature. Simplicia was weighed according to the body weight of the group of mice (Mus musculus) ie $400 \mathrm{mg} / \mathrm{kgBW}$ and $800 \mathrm{mg} / \mathrm{kgBW}$, then cut into small pieces and added with distilled water to a volume of $50 \mathrm{~mL}$ then heated over waterbath $\left(70^{\circ} \mathrm{C}\right)$ until the volume remained $10 \mathrm{~mL}$ is then filtered and cooled ${ }^{(7)}$.

\section{Measurement of cholesterol levels}

Measurement of cholesterol levels was carried out every 1 week. In the third week after administration of egg yolk was considered the result of hypercholesterolemia, the fifth week after administration of kapok parasite boiled water at a dose of $400 \mathrm{mg} / \mathrm{kgBW}$ for 2 weeks was considered the result of the first treatment, the fifth week after giving the parasite boiled water kapok at a dose of $800 \mathrm{mg} / \mathrm{kgBW}$ for 2 weeks is considered the result of the second treatment. Measurements were made by taking the blood of the test animal in the tail vein using surgical scissors, then the required blood was inserted into the measurement strip which automatically took $15 \mu \mathrm{m}$ of blood samples for one test.

\section{Hepar Histopahology Analysis}

Hepar was isolated and washed with $0.9 \%$ NaCl-phys. Preparation of hepar tissue section and staining was conducted based on previous methods with slight modification ${ }^{(8)}$.

\section{Result and Discussion}

The result boiled water parasite kapok (Dendrophthoe pentandra) leaves therapy on hepar of hypercholesterolemic mice (Mus musculus) total cholesterol showed decreasing of cholesterol levels (Table 1). 
Table 1. Average Value of Cholesterol Levels (mg / dL) of Mice (Mus musculus) Before and After Giving boiled water parasite kapok (Dendrophthoe pentandra) leaves.

\begin{tabular}{llcc}
\hline No & \multicolumn{1}{c}{ treatment } & \multicolumn{2}{c}{ Average total cholesterol (mg/d) } \\
\cline { 3 - 4 } & & I & II \\
\hline $\mathbf{1}$ & Control A & $92.00 \pm 9.11^{\mathrm{a}}$ & $96.20 \pm 8.62^{\mathrm{a}}$ \\
$\mathbf{2}$ & Hypercholesterolemia B & $156.20 \pm 12.30^{\mathrm{b}}$ & $158.80 \pm 11.66^{\mathrm{b}}$ \\
$\mathbf{3}$ & Treatment of $400 \mathrm{mg} / \mathrm{kgBW}(\mathrm{C})$ & $148.60 \pm 11.86^{\mathrm{b}}$ & $103.80 \pm 8.41^{\mathrm{a}}$ \\
$\mathbf{4}$ & Treatment of $800 \mathrm{mg} / \mathrm{kgBW}(\mathrm{D})$ & $154.40 \pm 11.23^{\mathrm{b}}$ & $97.60 \pm 8.71^{\mathrm{a}}$ \\
\hline
\end{tabular}

The average value of cholesterol levels in the first stage after cholesterol feeding showed that the normal group $(92.00 \pm 9.11 \mathrm{mg} / \mathrm{dL})$ was significantly different for all treatment groups, whereas in the hypercholesterolemia group $(156.20 \pm 12.30 \mathrm{mg} / \mathrm{dL})$ it was not significantly different from therapy dose of $400 \mathrm{mg} / \mathrm{kgBW}(148.60 \pm 11.86 \mathrm{mg} / \mathrm{dL})$ and $800 \mathrm{mg} / \mathrm{kgBW}(154.40 \pm 11.23 \mathrm{mg} / \mathrm{dL})$. The table shows that the average value of the lowest cholesterol level was in the normal group of $92.00 \mathrm{mg} / \mathrm{dL}$ while the average value of the highest cholesterol level was $156.20 \mathrm{mg} / \mathrm{dL}$ in the hypercholesterolemia group (Table 1). Statistical analysis also showed a significantly difference between groups $(\mathrm{p}<0.05)$.

The average second stage cholesterol level after administration of boiled water parasite kapok leaves showed that in the normal group $(96.20 \pm 8.62 \mathrm{mg} / \mathrm{dL})$ the effect was not significantly different from therapy dose of $400 \mathrm{mg} / \mathrm{kgBW}(103.80 \pm 8.41 \mathrm{mg} / \mathrm{dL})$ and $800 \mathrm{mg} / \mathrm{dL}(97.60 \pm 8.71 \mathrm{mg} / \mathrm{dL})$, whereas in the hypercholesterolemia group $(158.80 \pm 11.66 \mathrm{mg} / \mathrm{dL})$ had a very significant different effect on the three treatments, namely in the normal group, therapy dose $400 \mathrm{mg} / \mathrm{kgBW}$ and $800 \mathrm{mg} / \mathrm{kgBW}$. The average value of the lowest cholesterol level is in the normal group, which is equal to $(96.20 \pm 8.62 \mathrm{mg} / \mathrm{dL})$ while the average value of the highest cholesterol is in the hypercholesterol group at $(158.80 \pm 11.66 \mathrm{mg} / \mathrm{dL})$.

One parasite that contains high levels of flavonoids is Dendrophthoe pentandra that lives on kapok hosts. Dendrophtoe Petandra contains active compounds that can reduce cholesterol levels in the blood due to the antioxidant activity of flavonoids in the form of quercetin, saponins and tannins. The decrease in the activity of the enzyme Lipoprotein Lipase (LPL) is the effect of the overall process of severity of hypercholesterolemia ${ }^{(9)}$. The increase in LPL activity showed that the extract of the parasite mango water (Dendrophthoe pentandra) contained antioxidants. These antioxidants are believed to improve the process of bile acid synthesis. The bioactive which is believed to be found in the water extracts of mango parasites is flavonoids, saponins and tannins.

The boiled water parasite kapok leaves Dendrophthoe pentandra on hepar mice showed in Figure 1.In normal condition, showed normal central venous, sinusoid and hepatocyte. In group with hypercholesterolemia condition, showed an alteration as hepatocyte with fat degeneration, particulary the central vein. In groups with boiled water parasite kapok leaves therapy showed an improvement of hepar histopathology showed by decreasing of hepatocyte fat degeneration. In therapy group with dose of $800 \mathrm{mg} / \mathrm{kgBW}$ showed a repairing of hepatocyte to normal condition 


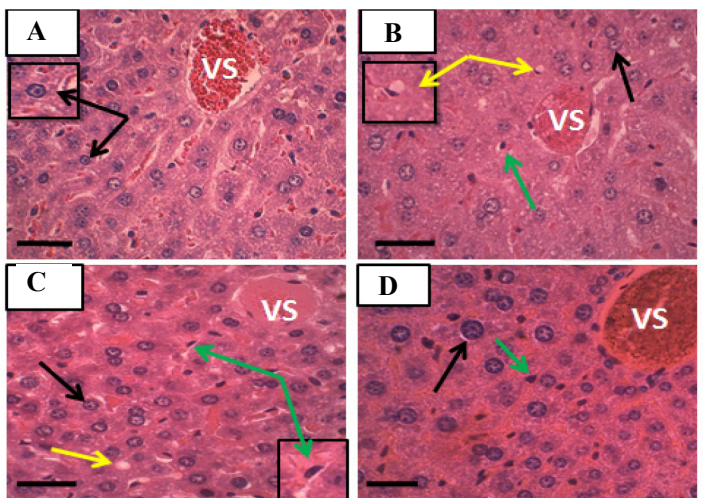

Figure 1. Histopathology of Hepar Hypercholesterolemia mice (Mus musculus) with HematoxilenEosine Staining (400x).

(A) control, (B) hypercholesterolemia, (C) therapy dose of $400 \mathrm{mg} / \mathrm{kgBW}$ and (D) therapy dose of $800 \mathrm{mg} / \mathrm{kgBW}$. Black arrow pointing to normal hepar cell, yellow arrow pointing to fatty hepatocyte, green arrow pointing to sinusoid.

Histopathological observations on liver tissue of mice found necrosis and degeneration of fat. Necrosis is a pathological death of one or more cells or parts of tissue or organ, which results from irreversible damage. This occurs when there is not enough blood flowing to the tissues, because of a disorder that one of them is fat degeneration. Fat degeneration is a change in morphology and a decrease in liver function caused by the accumulation of fat in the cytoplasm of liver cells, so that the cells look small patches of clear white fat and fat degeneration occurs because of LPL activity enzyme decreases VLDL hydrolysis that caused accumulation of trigliserides granules in hepatocytes. Fat accumulation commonly begins from the portal area that extend toward the central vein. This condition occurred of the blood supply from the intestine to the hepar through the central vein ${ }^{(10)}$. Hepar repairing showed by improvement of tissue caused of the antioxidant from boiled water parasite kapok (Dendrophthoe pentandra) leaves that causing the free radicals decrease by the reduction of blood cholesterol levels.

\section{Conclusion}

The boiled water parasite kapok (Dendrophthoe pentandra) leaves leaves for hypercholesterolemicrats therapy could decrease total cholesterol levels as well as improvement of hepar histopathology. Dose of $800 \mathrm{mg} / \mathrm{kgBW}$ was the best dose for hypercholesterolemia therapy.

\section{References}

[1] Tajoda, H.N., J.C. Kurian., and M.B. Bredenkamp., Reduction of Cholesterol and Triglycerides in Volunteer using Lemon and Apple, International Journal of Humanities and Social Science., 2013,Vol. 3,No. 18.

[2] Valkenburg, JLCH. Dendrophthoe pentandra (L.) Miq. In RHMJ Lemmens and N Bunyapraphatsara (Eds.) Plant Resources of South East Asia (PROSEA) 12, Medicinal and Poisonous Plants., 2003, (pp. 159-158). Bogor, Indonesia: Prosea Foundation

[3] Huaxing, Q, Hua-hsing, C, Hua-xing, K \& Gilbert, MG. 2003. Loranthaceae. Flora of China5: 220-239

[4] Kirana, C., R. Mastuti, M.A. Widodo, S.B. Sumitro, S. Indriyani, dan B. Alfi. 2001. Komposisi Bahan Bioaktif Benalu. Jurnal Ilmu-Ilmu Teknik (Engineering)., 2001, Vol. 13 (2); 193204. 
[5] Rufaida, Fanny, Aulanni'am \& Sri Murwani. 2006. Profil Kadar Kolesterol Total, Low Density Lipoprotein (LDL) Dan Gambaran Histopatologis Aorta Pada Tikus (Rattus Norvegicus) Hiperkolesterolemia Dengan Terapi Ekstrak Air Benalu Mangga (Dendropthoe Pentandra). Program Studi Pendidikan Dokter Hewan Universitas Brawijaya

[6] Artanti N, T Firmansyah and A Darmawan. 2012. Bioactivities Evaluation of Indonesian Mistletoes (Dendrophthoe pentandra L.) Miq.) Leaves Extracts. Journal of Applied Pharmaceutical Science., 2012 Vol. 02 (01):24-27

[7] Riesanti,D.G, Masdiana, Herawati. 2008. Kadar HDL, Kadar LDL, dan Gambaran Histopatologi Aorta Pada Hewan Model Tikus (Rattus norvegicus) Hiperkolesterolemia dengan Terapi Ekstrak Air Benalu Mangga (Dendrophthoe pentandra). Program Studi Kedokteran Hewan. Universitas Brawijaya. Malang.

[8] Nurjanah, LI. dan A. Asadatun., Antioxidant activity dan bioactive compound of Solenspp, Ilmu Kelautan, 2011, 16 (3) 119-124

[9] Ramadani, P.R, Aulanni'am, Herawati. 2013. Potensi Ekstrak Air Benalu Mangga (Dendrophtoe petandra) Terhadap Aktivitas Enzim Lipoprotein Lipase (LPL) Serum Dan Histopatologi Duodenum Hewan Model Tikus (Rattus norvegicus) Hiperkolesterolemia. Program Studi Pendidikan Dokter Hewan, Universitas Brawijaya. Vol 2 (3)

[10] Singh, R., S. Kumar., A.C. Rana., and N. Sharma., Different Models of Hepatotoxicity and Related Hepar Diseases. IRJP, 2012, 3 (7). 